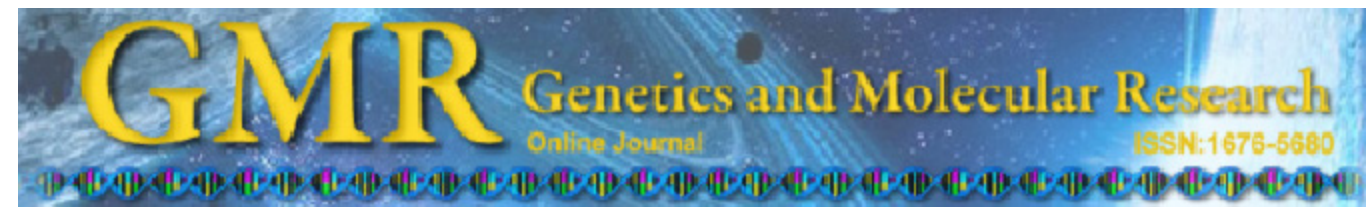

\title{
Genetic and morphological diversity of Moenkhausia oligolepis (Characiformes: Characidae) populations in the tributaries of the Araguaia River, Brazil: implications for taxonomy and conservation
}

\author{
T.J. Domingos ${ }^{1}$, L.N. Moraes ${ }^{1}$, R.M. Moresco ${ }^{2}$, V.P. Margarido ${ }^{2}$ and \\ P.C. Venere ${ }^{1}$ \\ ${ }^{1}$ Laboratório de Ictiologia GEPEMA, Instituto de Ciências Biológicas e da Saúde, \\ Universidade Federal de Mato Grosso, Pontal do Araguaia, MT, Brasil \\ ${ }^{2}$ Laboratório de Genética, Centro de Ciências Biológicas e da Saúde, \\ Universidade Estadual do Oeste do Paraná, Cascavel, PR, Brasil \\ Corresponding author: P.C. Venere \\ E-mail: pvenere@uol.com.br
}

Genet. Mol. Res. 13 (3): 7979-7991 (2014)

Received August 26, 2013

Accepted January 22, 2014

Published September 29, 2014

DOI http://dx.doi.org/10.4238/2014.September.29.11

\begin{abstract}
Molecular genetic assessments that consider ecological information, in addition to endogamy levels, genetic diversity, and the genetic differentiation among species and populations, are particularly important for the conservation of biological diversity. Prime candidates for conservation genetic review are those subject to human use, including harvests for the ornamental fish trade. Colorful South American tetra, such as Moenkhausia oligolepis and M. forestii, are good examples of fish species that are widely collected and exported worldwide. This study aimed to evaluate the population-specific characteristics of $M$. oligolepis and M. forestii by comparing morphometric and molecular analyses based on ISSR markers, to provide information that would
\end{abstract}


facilitate the sustainable management of these 2 species. Seventytwo specimens were collected from the Araguaia-Tocantins and Paraguay River Basins in Brazil. All specimens were measured and analyzed using ISSR markers. Population-exclusive bands were found among the 86 detected bands, while morphometric clusters reflected the geographical distribution of individuals. Correlated genetic and morphological variation supported the presence of 3 distinct groups from tributaries of the Araguaia and Mortes Rivers. Using the same techniques, all M. oligolepis populations were isolated from M. forestii. This study on Moenkhausia presents an interesting example that could be used to construct a framework of South American ichthyodiversity, and reinforces the necessity of habitat conservation to prevent the loss of biological diversity.

Key words: Conservation genetics; Fishes; ISSR; Molecular markers; Morphometric analyses

\section{INTRODUCTION}

Data about the genetic diversity of species represent fundamentally important tools for the protection and management of natural populations. Protection is particularly important when the existence of variant forms within a species is favored by selection and adaptation processes. Such variation tends to occur when the environments experienced by populations of a given species differ among distinct locations within the distribution range of a given species (Mills, 2004). Populations are dynamic, whereby they increase or decrease based on changes in the birth and death rates, or by migration or fusions with other populations. This phenomenon has important consequences, which may lead to changes in their genetic pool over time (Klug and Cummings, 1997). Small populations tend to present low genetic variability, with inbreeding resulting in a reduction in the fecundity and viability of individuals.

Several molecular markers have been used in genetic diversity and conservation biology studies (Avise, 1996), with the aim of defining priorities for the conservation of endangered species or for population management (Moritz, 1994), developing demographic models of small or fragmented populations (Lacy and Lindenmayer, 1995), and analyzing the adaptive value of natural or captive populations (Lynch, 1996). A few markers have been used to analyze sections of the genome composed by repeated simple sequences, which consist of 1 to 6 tandemly repeated nucleotides, termed microsatellite markers [namely, simple sequence repeats (SSRs) or inter-SSRs (ISSRs)]. The method used to analyze ISSRs (Zietkiewicz et al., 1994; Reddy et al., 2002) is microsatellite-based, but does not require previous knowledge about the genome. The ISSR-based analysis utilizes a microsatellite sequence, usually 16-25 $\mathrm{bp}$ in length, to amplify sequences of different sizes that are located between the microsatellites. ISSR markers are composed of nucleotide trios that act between microsatellite regions (Lalhruaitluanga and Prasad, 2009), and are amplified by the use of a single primer each time. A major advantage of the ISSR method is that it does not require the time-consuming (and expensive) step of genomic (or other) library construction (Rakoczy-Trojanowska and Bolibok, 2004). ISSR also has other advantages when compared to the random amplification of poly- 
morphic DNA (RAPD) technique (9-10-bp primers), because it ensures higher reproducibility, due to the use of longer primers (16-25 bp), which permit the use of high annealing temperatures $\left(45-60^{\circ} \mathrm{C}\right)$ leading to higher stringency (Reddy et al., 2002). Thus, the ISSR technique allows the fast evaluation of population genetic diversity, because it creates estimated levels of genetic diversity between or within different animal populations (Maltagliati et al., 2006; Pazza et al., 2007; Moysés et al., 2010).

The Neotropics contains large ichthiodiversity; hence, studies in this region have been conducted for several years in an attempt to improve species identification and taxonomy (Foresti et al., 1989; Lucinda et al., 2007). Within this framework, studies carried out on small characids using chromosomal (Moreira-Filho and Bertollo, 1991) and molecular markers (Oliveira et al., 2011) have contributed valuable information about fish genetic diversity. As occurs in many other Characidae fish groups, their diversity has yet to be explored, such as for the fish that belongs to the Moenkhausia genus. This genus was proposed by Eigenmann (1903), and has been defined as being comparable to Tetragonopterus, but with a slightly downward curved lateral line (Benine et al., 2007). At present, Moenkhausia is represented by 75 valid species that occur in South American River Basins (Froese and Pauly, 2013).

According to Mirande (2010), Javonillo et al. (2010), and Oliveira et al. (2011), Moenkhausia was previously demonstrated to be a polyphyletic unit. In addition, Benine et al. (2009) stated that the individuals from four species within this genus possesses the following characteristics: black borders on its scales, a vertically elongated humeral blotch, a dark blotch on the caudal peduncle preceded by a brighter area, and, frequently, dark red eyes when alive. This group of species consists of M. oligolepis (Gunther, 1864), M. sanctaefilomenae (Steindachner, 1907), M. cotinho (Eigenmann, 1903), and M. pyrophthalma Costa, 1994. Hence, there is need to obtain more information about these species, with the aim of resolving taxonomic questions about the Moenkhausia genus. Such information would contribute to the establishment of robust conservation priorities, as well as redefining biodiversity values for species such as $M$. oligolepis. For instance this species occurs sympatrically with many other species that exhibit similar color patterns; thus, resulting in its conservation status being wrongly defined, leading to actions that may threaten the survival of this species.

Evaluations of the population genetic structure of given species provide a genetic overview about the populations, revealing differentiation among individuals, genetic diversity, and endogamy levels. These data are associated with knowledge about species attributes; for instance, effective population size, gene flow, and mating systems are particularly important in the formulation of management actions for adoption. Examples include decisions to manage separate or single fish stocks in fisheries management (Coyle, 1997), or to regulate harvesting to protect depleted populations by the identification and regulation of genetic changes within a population. Such changes to the genetics of a species may have drastic and long-term effects on its populations, as consequence of differential harvest rates within populations (Çiftci and Okumus, 2002). In the long term, conservation goals focus on avoiding endogamy in populations that are not normally endogamic (Nicoara, 2004), allowing the maintenance of the highest possible evolutionary potential (Carvalho and Hauser, 1998).

The present study analyzed the morphology and genetic diversity of M. oligolepis populations from the Araguaia-Tocantins River Basin, Brazil, to improve our understanding about the taxonomic framework and population genetic structure in the group. To obtain a better comparison and evaluation of the applied methodology, specimens of $M$. forestii from 
the Alto Paraguay River Basin, which were recently described as being different to the $M$. oligolepis complex, were also included.

\section{MATERIAL AND METHODS}

Seventy-two specimens were sampled from both species, at 4 distinct locations. Specifically, 52 specimens of $M$. oligolepis were collected, of which 31 specimens were from the Taquaralzinho Stream $\left(15^{\circ} 40^{\prime} 42^{\prime \prime} \mathrm{S}, 52^{\circ} 17^{\prime} 52^{\prime \prime} \mathrm{W}\right)$, an indirect tributary of the Mortes River (Araguaia-Tocantins Basin), 9 specimens were from a small creek located at Itapirapuã ( $15^{\circ}$ $\left.49^{\prime} 30^{\prime \prime} \mathrm{S}, 50^{\circ} 36^{\prime} 05^{\prime \prime} \mathrm{W}\right), 12$ specimens were from a small creek in the municipality of Pontal do Araguaia ( $\left.15^{\circ} 54^{\prime} 38^{\prime \prime} \mathrm{S}, 52^{\circ} 15^{\prime} 41^{\prime \prime} \mathrm{W}\right)$, with both creeks being tributaries of the Araguaia River (Araguaia-Tocantins Basin). In addition, 20 specimens of $M$. forestii were collected from the Paraguay River (Paraguay Basin), in the Reserva Nacional do Patrimônio Natural do Serviço Social do Comércio Pantanal-RPPN Sesc Pantanal (16 31' 07" S, 56 22' 42" W) (Figure 1).

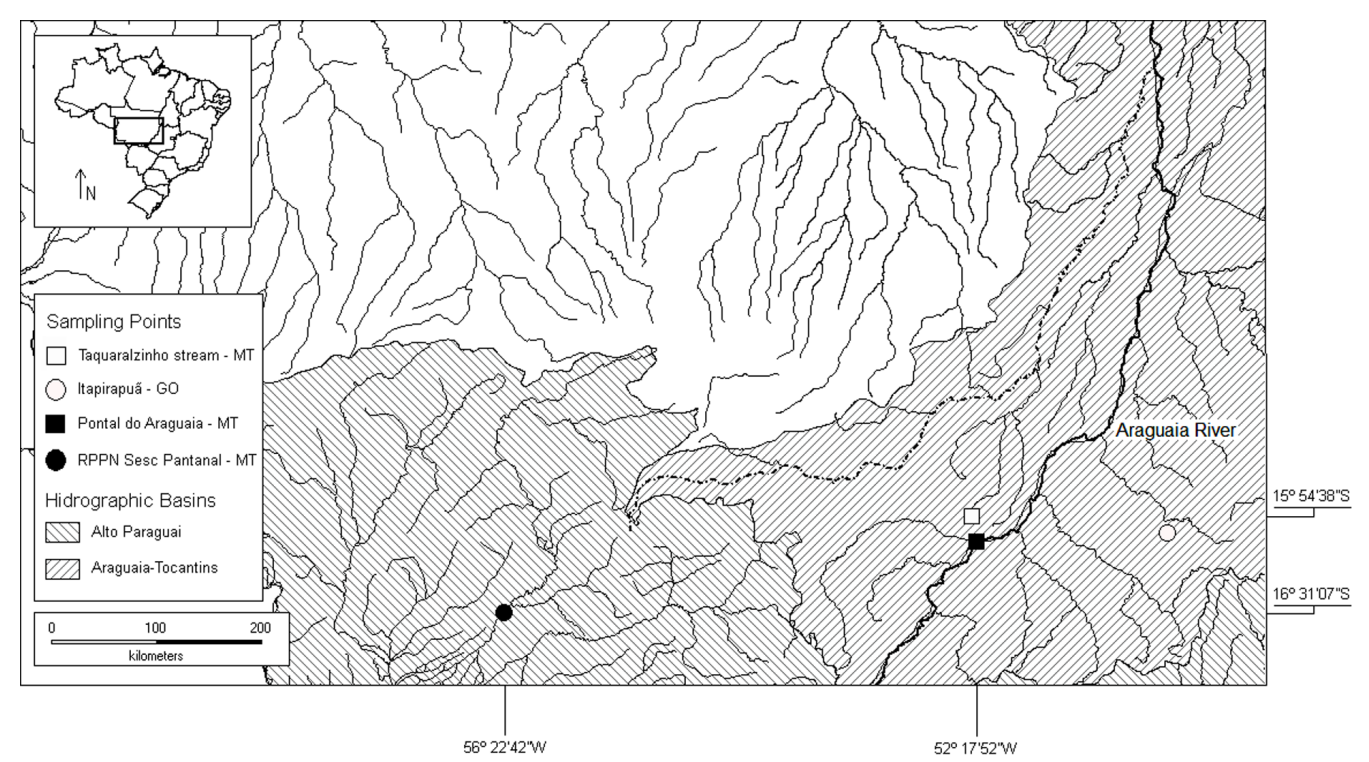

Figure 1. Sampling sites of Moenkhausia oligolepis: Taquaralzinho Stream; Itapirapuã; Pontal do Araguaia. Sampling point of M. forestii: RPPN Sesc Pantanal. Mortes River and Araguaia River.

All of the specimens were preserved in $100 \%$ alcohol, and transported to the laboratory of the Grupo de Estudos em Peixes do Médio Araguaia (GEPEMA/CNPq/UFMT) for tissue sampling (muscles and/or liver) for DNA extraction. Subsequently, the fishes were measured and deposited in the Ichthyology collection of GEPEMA as voucher specimens (serial numbers: ICLMA629 to ICLMA634).

The morphometric analyses were completed based on 12 body measurements of 50 of the 72 specimens; of these, 30 were M. oligolepis ( 9 from the Taquaralzinho Stream, 9 from 
Itapirapuã-GO, and 12 from Pontal do Araguaia-MT) and 20 were M. forestii from the RPPN SESC Pantanal. The following measurements were recorded using a digital caliper rule with $0.01 \mathrm{~mm}$ precision: standard length; eye diameter; pre-dorsal distance; body height; interorbital distance; caudal peduncle height; dorsal fin base length; pre-adipose distance; postadipose distance; anal fin base length; head length; and head height. The measurements of the specimens represented a numerical matrix that was used in a Canonical Variable Analysis and Principal Component Analysis (PCA) by PAST software (Khattree and Naik, 2000). However, in the PCA, the original data were transformed into proportions, by dividing each body measurement by the standard length of each individual, and excluding the standard length from the analysis. Both methods were used because there is an ongoing debate about which is the most accurate; hence, the acceptance and credibility of one is only matched by the other.

The DNA extraction from muscular and/or liver tissue primarily followed the phenolchlorophormium protocol described by Sambrook et al. (1989). The DNA quantification and quality analysis were conducted using Eppendorf Biophotometer Plus (Eppendorf Hamburg, Hamburg, Germany). Subsequently, the DNA samples were diluted to a final concentration of $70 \mathrm{ng} / \mu \mathrm{L}$.

For ISSR amplification, the following primers were previously selected and used: M1 $(\mathrm{GGAC})_{4}, \mathrm{M} 2(\mathrm{GGAC})_{3} \mathrm{~A}, \mathrm{M} 3$ (GGAC) $_{3} \mathrm{~T}, \mathrm{M} 4(\mathrm{GGAC})_{3} \mathrm{C}$, and M5 (AACC) $)_{4}$. Polymerase chain reaction (PCR) markers were developed according to Fernandes-Matioli et al. (2000), as summarized here. In brief, the amplifications were completed in a $25-\mu \mathrm{L}$ reaction mixture, containing $70 \mathrm{ng}$ DNA, $0.5 \mu \mathrm{M}$ primer, $0.2 \mathrm{mM}$ dNTP, $1 \mathrm{X}$ buffer $200 \mathrm{mM}$ Tris-HCl, $\mathrm{pH}$ 8.4, 500 $\mathrm{mM} \mathrm{KCl}, 1.5 \mathrm{mM} \mathrm{MgCl}_{2}$, and 0.6 Recombinant Taq DNA polymerase (Invitrogen). Negative controls without DNA were included in each set of amplifications. The amplification conditions included 1 cycle of $45 \mathrm{~s}$ at $94^{\circ} \mathrm{C}, 1 \mathrm{~min}$ at $51^{\circ} \mathrm{C}$, and $1 \mathrm{~min}$ at $72^{\circ} \mathrm{C}$, followed by 29 cycles of 45 s at $94^{\circ} \mathrm{C}, 1 \mathrm{~min}$ at $48^{\circ} \mathrm{C}$, and $1 \mathrm{~min}$ at $72^{\circ} \mathrm{C}$, with a final extension of $10 \mathrm{~min}$ at $72^{\circ} \mathrm{C}$. The PCR products were separated and analyzed on $10 \%$ polyacrylamide gel stained with silver nitrate. The gels were photodocumented using a 2 UV Transilluminator for posterior analysis.

Each amplified ISSR fragment that was visualized on gel was considered an independent allele that was coded present or absent for each specimen. Bands with the same molecular weight, but generated by the use of different primers, were considered independent, due to the nucleotide constitution of the primers. Thus, a matrix based on the presence (1) or absence (0) of bands on gels was generated and used to calculate genetic identity, genetic distance, and intra- and interpopulation variation. The pairwise distance matrix between individuals was obtained by the Nei and Li similarity index, and used to construct the neighbor-joining dendrogram with the program Free Tree (Pavlicek et al., 1999) and Mega 3.1 (Kumar et al., 2004). The scatter plot of the principal coordinates was constructed using the programs Dist PCoA and Statistica 7.1. Genetic differentiation was estimated by applying the Mantel test, with 10,000 permutations for the Nei and Li similarity matrix using the Mantel-Struct 1.0 program. The analysis of molecular variance and the value of genetic differentiation $\left(F_{\mathrm{ST}}\right)$ were obtained using the program Arlequin 3.5.1.2, which defined, a priori, the M. forestii population as external group to the populations of M. oligolepis.

\section{RESULTS}

The Canonical Variable Analysis assigned the individuals to 4 morphologically defined groups, according to their places of origin (Figure 2). The M. oligolepis populations from Itapirapuã and Pontal do Araguaia presented very similar morphometrics, whereas the 
M. oligolepis population from Taquaralzinho and the $M$. forestii population presented different morphologies compared to the first 2 populations.

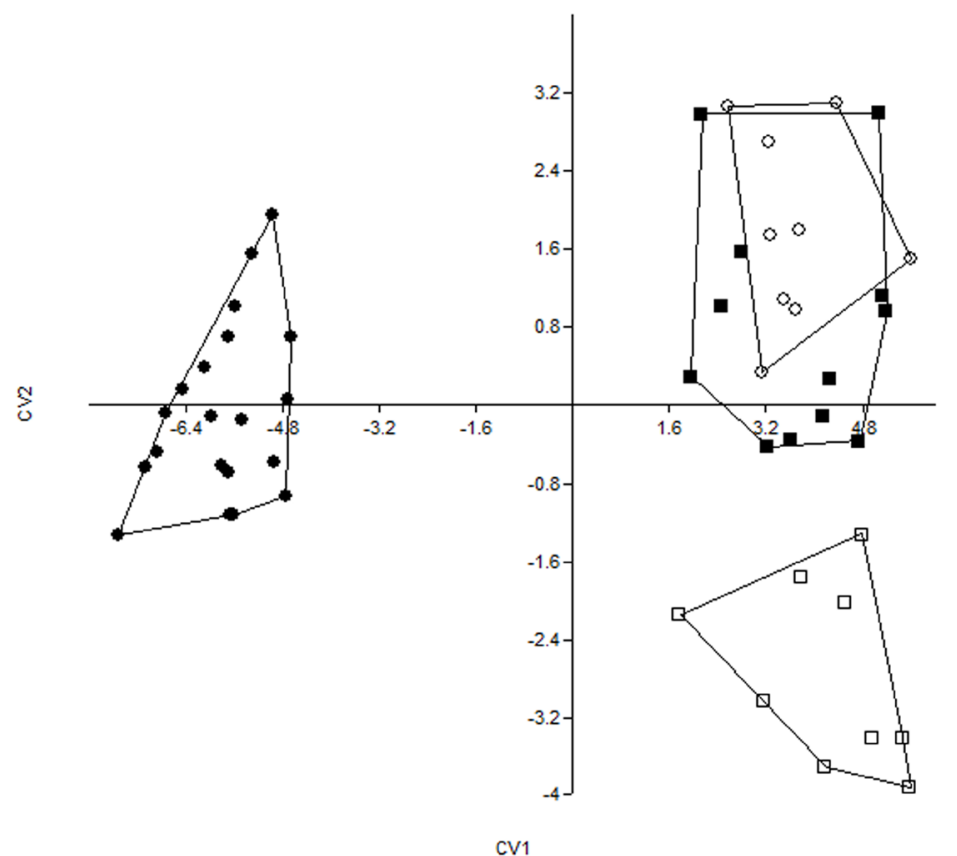

Figure 2. Morphological variation of 50 individuals according to the Canonical Variables Analysis. Empty circles: Moenkhausia oligolepis (Itapirapuã); filled squares: M. oligolepis (Pontal do Araguaia); empty squares: $M$. oligolepis (Taquaralzinho); filled circles: M. forestii (RPPN Sesc Pantanal).

The first analysis axis (Axis 1) shows a morphological variation of $89.5 \%$, whereas the second axis presents $8.4 \%$ of the variation. The variable that most contributed to the formation of the dot distribution pattern along the Axis 1 was the standard length, whereas body height was responsible for the distribution pattern along the Axis 2.

PCA assigned the individuals in groups with similar morphological distribution (Figure 3). M. forestii remained the most discrepant population, while the Taquaralzinho and Itapirapuã population distributions did not overlap. However, in this analysis, the Pontal do Araguaia $M$. oligolepis population seemed to share morphological characteristics with the other populations of $M$. oligolepis.

The first principal component ( $\mathrm{PC} 1)$ presented $75.35 \%$ of the variation, while the second principal component (PC2) presented $7.61 \%$. The variable that most contributed to PC1 was pre-dorsal distance, with a loading value of 0.9713 . The strongest contributors to PC2 were body height, anal fin base length, and head length, with loading values of 0.5808 , 0.5098 , and 0.4656 , respectively.

ISSR analysis detected 86 loci ( 86 differentiable bands on gels) with 0.599 intrapopulation and 0.401 interpopulation variation, and exclusive alleles being detected in some populations (Figure 4). 


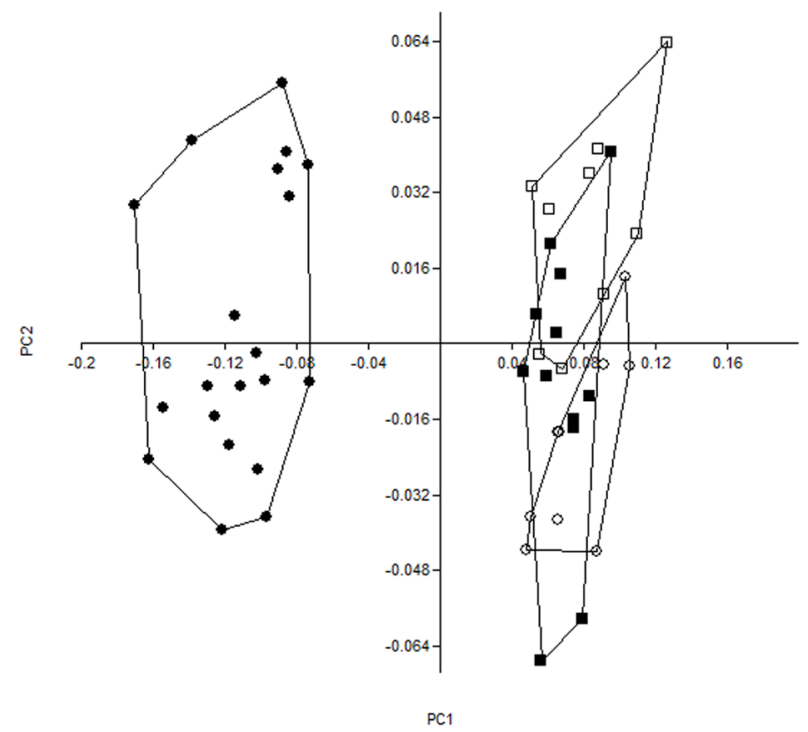

Figure 3. Morphological variation of 50 individuals according to the Principal Component Analysis. Empty circles: Moenkhausia oligolepis (Itapirapuã); filled squares: M. oligolepis (Pontal do Araguaia); empty squares: $M$. oligolepis (Taquaralzinho); filled circles: M. forestii (RPPN Sesc Pantanal).

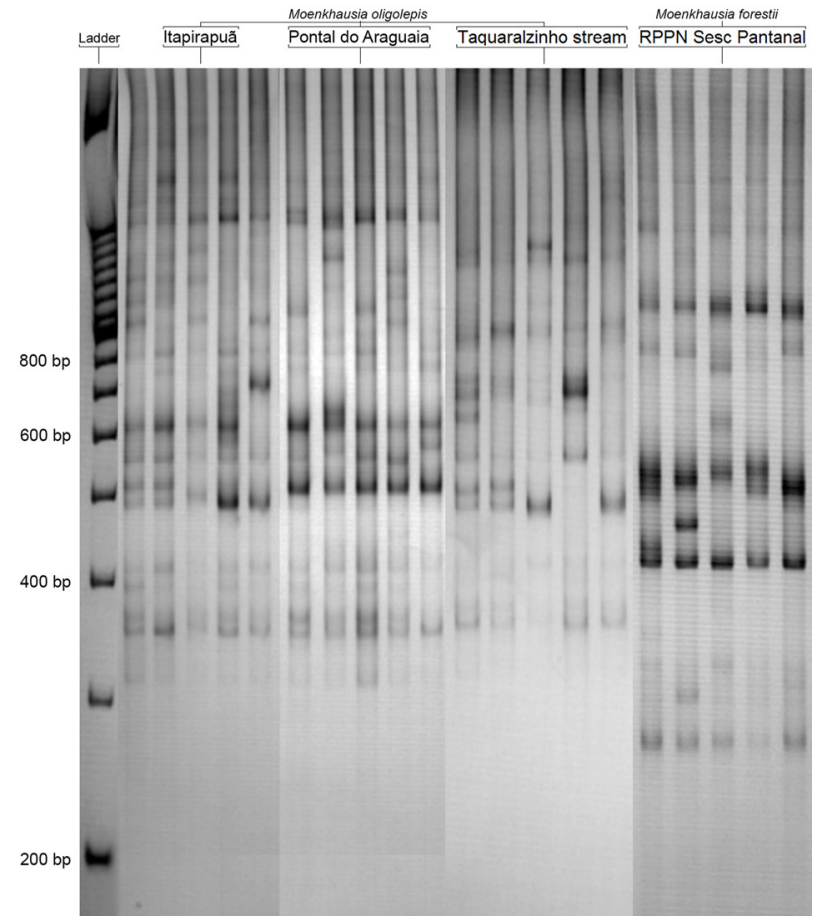

Figure 4. Analysis of Moenkhausia oligolepis and M. forestii populations through ISSR marker: polyacrylamide gel electrophoresis of PCR products was obtained after the amplification of DNA samples from 5 individuals from each population using the primer M1 (GGAC) $)_{4}$. 
The dendrogram analysis identified 2 main groups (M. oligolepis and M. forestii species), with a clear relationship among the $M$. oligolepis populations. In addition, higher genetic distance was detected between the populations from Taquaralzinho and Pontal do Araguaia (Figure 5), which inhabit the opposite sides of the Serra do Taquaral mountain range, and belong to different micro-basins.

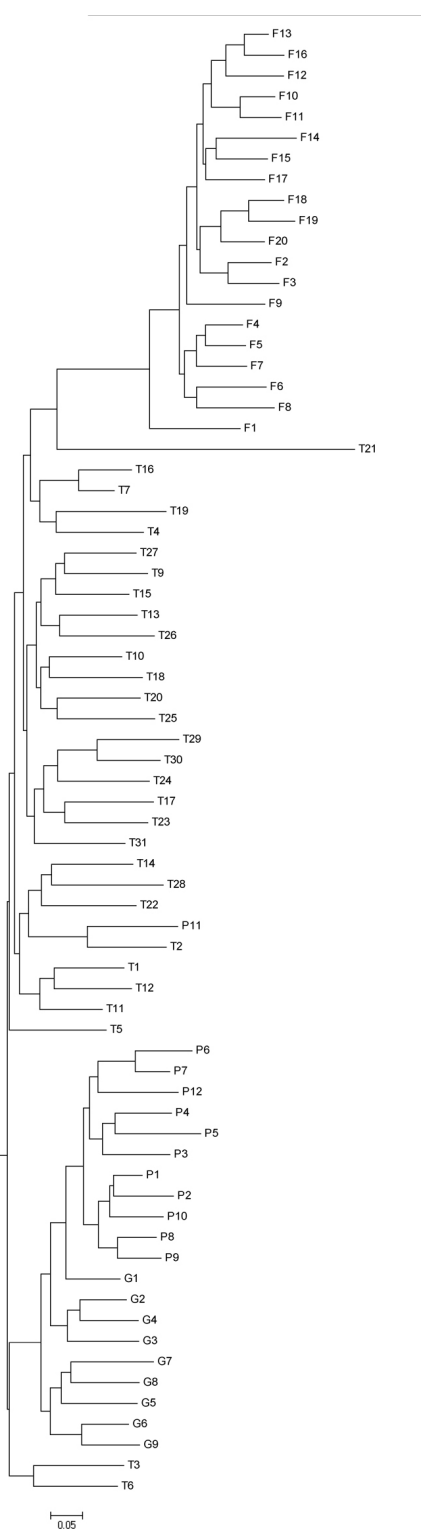

Figure 5. Neighbor-joining dendrogram using ISSR marker data. The individuals are coded by sampling points: G1-G9: Itapirapuã; P1-P12: Pontal do Araguaia; T1-T31: Taquaralzinho Stream; F1-F20: RPPN Sesc Pantanal (Moenkhausia forestii). 
The PCA scatter plot was built with the 2 major eigenvectors, from the Nei and Li similarity indexes, and agreed with the dendrogram (Figure 6).

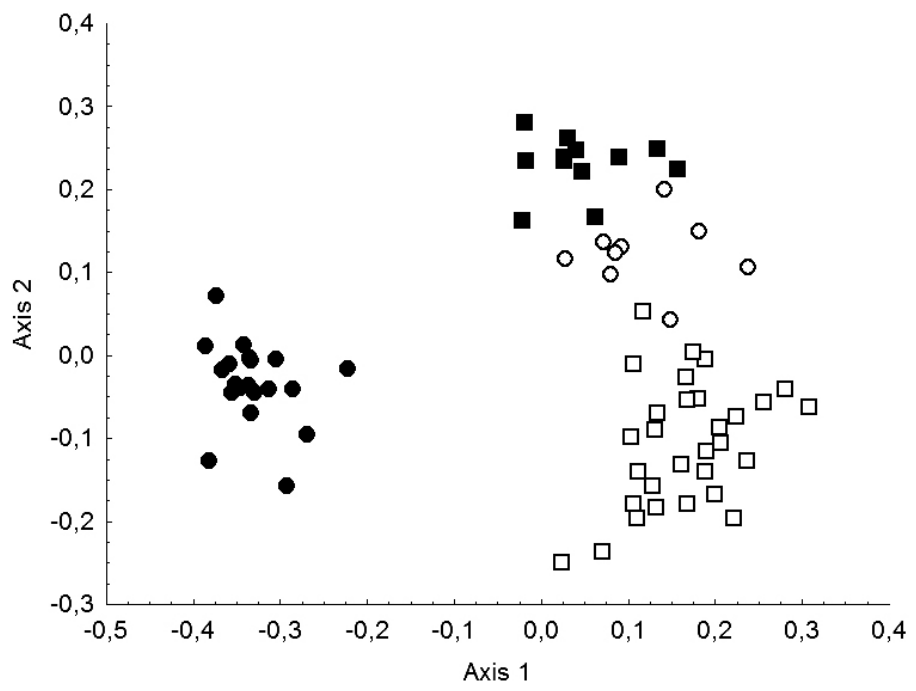

Figure 6. Scatter plot of principal coordinates based on Nei and Li similarity indexes calculated from the matrix of presences and absences of bands on gels amplified with ISSR markers. Empty circles: Moenkhausia oligolepis (Itapirapuã); filled squares: M. oligolepis (Pontal do Araguaia); empty squares: M. oligolepis (Taquaralzinho); filled circles: M. forestii (RPPN Sesc Pantanal).

The genetic differentiation among populations quantified by the Mantel test proved significant correlation among the 3 M. oligolepis populations $\left(\mathrm{P} \leq 0.051, \mathrm{r} \geq 0.172\right.$ and $\left.\mathrm{Z}_{10,000}<\mathrm{Z}\right)$, and between M. oligolepis and M. forestii $\left(\mathrm{P} \leq 0.001, \mathrm{r} \geq 0.792\right.$ and $\left.\mathrm{Z}_{10,000}<\mathrm{Z}\right)$, confirming that these populations/species are genetically differentiated. Values of genetic dissimilarity, i.e., the genetic variability within and among populations, were also obtained through this test (Table 1).

Table 1. Pairwise comparisons of Moenkhausia population genetic dissimilarity using Nei and Li coefficient.

\begin{tabular}{lccrrrr}
\hline Pairwise comparisons & $F_{\mathrm{ST}}$ & $\mathrm{P}$ & $\mathrm{r}$ & $\mathrm{Z}$ & $\mathrm{Z}_{10,000}$ & Genetic dissimilarity \\
\hline M. oligolepis (Itapirapuã x Pontal do Araguaia) & 0.223 & 0.001 & 0.519 & 36,450 & 32,484 & 0.338 \\
M. oligolepis (Itapirapuã x Taquaralzinho) & 0.204 & 0.051 & 0.172 & 113,101 & 106,441 & 0.419 \\
M. oligolepis/Itapirapuã x M. forestii/RPPN Sesc Pantanal & 0.520 & 0.001 & 0.917 & 97,065 & 68,964 & 0.539 \\
M. oligolepis (Pontal do Araguaia x Taquaralzinho) & 0.308 & 0.001 & 0.459 & 171,743 & 150,201 & 0.477 \\
M. oligolepis/Pontal do Araguaia x M. forestii/RPPN Sesc Pantanal & 0.508 & 0.001 & 0.921 & 124,979 & 92,164 & 0.521 \\
M. oligolepis/Taquaralzinho x M. forestii/RPPN Sesc Pantanal & 0.451 & 0.001 & 0.792 & 355,411 & 281,226 & 0.592
\end{tabular}

Interpopulation genetic differentiation index $\left(F_{\mathrm{ST}}\right)$, significance level $(\mathrm{P})$, correlation of two matrices $(\mathrm{r})$, robustness of the relation original data $(\mathrm{Z})$ and after 10,000 permutations $\left(\mathrm{Z}_{10,000}\right)$, genetic dissimilarity using Nei and $\mathrm{Li}$ coefficient.

The intrapopulation genetic dissimilarity was almost the same in the 3 M. oligolepis populations: 0.265 in Itapirapuã, 0.260 in Pontal do Araguaia, and 0.255 in Pantanal. The highest dissimilarity was found in the population of Taquaralzinho (0.392). The indexes of interpopulation genetic differentiation $\left(F_{\mathrm{ST}}\right)$ were as follows: 1) high between M. oligolepis 
and $M$. forestii $\left(F_{\mathrm{ST}} \geq 0.451\right)$ and between the $M$. oligolepis populations of Pontal do Araguaia and Taquaralzinho $\left(F_{\mathrm{ST}}=0.308\right)$; and 2$)$ moderate between the M. oligolepis populations of Itapirapuã and Pontal do Araguaia $\left(F_{\mathrm{ST}}=0.223\right)$ and between the M. oligolepis populations of Itapirapuã and Taquaralzinho $\left(F_{\mathrm{ST}}=0.204\right)($ Table 1$)$.

\section{DISCUSSION}

In the present study, the results showed that the genetic diversity of the analyzed populations was correlated with morphological variation, supporting the concept of isolation. The results from the canonical variable analysis indicated that $M$. oligolepis individuals that occur on the south slope of the Serra do Taquaral (Araguaia River Basin) are reproductively isolated from the individuals that occur on the north slope of the Serra do Taquaral (Rio das Mortes River Basin), as much as the individuals of M. oligolepis from the Araguaia-Tocantins River Basin are isolated from $M$. forestii individuals from the Paraguay River Basin. In parallel, the PCA results also indicated that isolation is occurring, but only between the Taquaralzinho (on the north slope of Serra do Taquaral-Rio das Mortes River Basin) and Itapirapuã (on the east side of the Araguaia-Tocantins River Basin) populations. This method produced different results to the PCoA, indicating that there is movement of individuals between the south and north slopes of the Serra do Taquaral (Taquaralzinho and Pontal do Araguaia). Therefore, individuals from the east side of the basin (Itapirapuã) reach the middle of the basin (Pontal do Araguaia), but do not reach the north slope of the Serra do Taquaral. Morphologically, the $M$. oligolepis population from the Taquaralzinho tributary is only slightly similar to the population from the Pontal do Araguaia, but is isolated from the other 2 populations, almost as much as $M$. forestii is isolated from $M$. oligolepis. This relationship was also demonstrated by the ISSR results $\left(F_{\mathrm{ST}} \geq 0.451 ;\right.$ Table 1$)$. These results indicate that, as $M$. forestii once belonged to the M. oligolepis complex as a population from Paraguay River Basin (Benine et al., 2009), the same may apply for the M. oligolepis population from the Taquaralzinho tributary. The presence of several exclusive alleles among the 4 studied $M$. oligolepis populations reinforces the concept of reproductive isolation among them.

The frequency analysis of non-exclusive alleles among the populations and the neighbor-joining clustering demonstrated that the genetic distance is sufficient to separate the individuals into 3 defined groups: M. oligolepis Itapirapuã-Pontal do Araguaia group, $M$. oligolepis Taquaralzinho group, and $M$. forestii group. Likewise, the data obtained through molecular variance revealed that, despite the populations having high genetic diversity when considered as a whole, significant $F_{\mathrm{ST}}$ values between each pair of populations was revealed, indicating the presence of reproductive isolation among them.

The efficiency of ISSR markers in this study was very satisfactory, supporting previous studies of genetic diversity evaluation in fish species, such as Cichla (Almeida-Ferreira et al., 2011), Astyanax fasciatus (Cuvier, 1819) (Pazza et al., 2007), Paralichtys olivaceus (Temminck and Schlegel, 1846) (Liu et al., 2006), Valencia hispanica (Valenciennes, 1846), Valencia letourneuxi (Sauvage, 1880), and Aphanius fasciatus (Valenciennes, 1821) (Maltagliati et al., 2006). Leuzzi et al. (2004) performed a study with Astyanax altiparanae Garutti \& Britski, 2000 populations that were isolated due to the installation of dams on the Paranapanema River, Brazil, and presented high levels of genetic differentiation downstream of the Capivara Dam. Prioli et al. (2002) also studied Astyanax altiparanae, and found high 
genetic diversity in populations, combined with low levels of isolation and high levels of genetic flow on the Iguaçu River, at points where they were not isolated by geographical barriers, such as dams.

The combined application of different tools for the characterization of populations and/or species may produce consistent analyses. Examples of such tools include morphometric analysis, DNA marker analysis, and karyotypical structure or chromosome banding. Pazza et al. (2007) analyzed populations of Astyanax fasciatus with RAPD markers, ISSR, and cytogenetic techniques, and obtained interesting results. The authors found that the ISSR markers revealed small genetic differences among populations, even though 2 distinct sympatric karyomorphs had been detected ( $2 n=46$ and $2 n=48$ chromosomes). This finding demonstrates that cytogenetic differences could pass unnoticed in studies that solely use molecular markers analysis, while molecular differences could also pass unnoticed in cytogenetic studies.

The species from the Moenkhausia genus have diploid numbers of 48 and 50 chromosomes (Foresti et al., 1989). In addition, M. sanctaefilomenae, one of the species with a morphology very similar to those of M. oligolepis, shares the same chromosome number $(2 \mathrm{n}=50)$, but with the addition of B chromosomes to its karyotype (de Brito Portela-Castro et al., 2000). However, cytogenetic studies remain insufficient to detect differences among populations that indicate some kind of isolation. This is the case for this species group in the current study, where molecular and morphological analysis detected a group of individuals in the Taquaralzinho Stream (Araguaia-Mortes Basin) that is very distinct from the other populations; hence, indicating that this population is isolated, and possibly restricted to this micro-basin. Carvalho (1993) emphasized that locally adapted genetic pools are fragile, and that the conservation of genetic resources should not only include practices to maximize genetic diversity levels, but also, measures to preserve genotypic variation associated with significant ecological traces.

The results of the present study demonstrate that the M. oligolepis complex is currently formed by populations that have restricted distributions along the headwater streams and river continuum. The geographic isolation of the headwaters and small streams, the environmental variation between them, and individual adaptability all represent the raw material for the emergence of new species and their variants, as happened with $M$. forestii in the Paraguay River Basin, and may occur with M. oligolepis in the Mortes River Basin. This study reinforces the necessity of habitat conservation, where this species complex and several other aquatic species occur, to prevent the loss of biological diversity. Moenkhausia oligolepis, like several other fish species (Hoplias malabaricus, Bertollo et al., 2000; Astyanax scabripinnis, Bertaco and Lucena, 2006; Astyanax aff. fasciatus, Artoni et al., 2006; among others), constitute complexes of species that must be recognized and described, contributing to a realistic representation of South American ichthyodiversity.

\section{ACKNOWLEDGMENTS}

The authors are grateful to the Instituto Brasileiro do Meio Ambiente e dos Recursos Naturais Renováveis for the licence expedition (IBAMA/SISBIO - License \#15226-1). Research supported by Fundação de Amparo à Pesquisa do Estado de Mato Grosso (FAPEMAT \#453511/2009) and Conselho Nacional de Desenvolvimento Científico e Tecnológico (CNPq \#477057/2009-8). 


\section{REFERENCES}

Almeida-Ferreira G, Oliveira AV, Prioli AJ and Prioli SMAP (2011). Spar genetic analysis of two invasive species of Cichla (tucunaré) (Perciformes: Cichlidae) in the Paraná river basin. Acta Sci. Biol. Sci. 33: 79-85.

Artoni RF, Shibatta OA, Gross MC, Schneider CH, et al. (2006). Astyanax aff. fasciatus Cuvier, 1819 (Teleostei; Characidae): evidences of a species complex in the upper rio Tibagi basin (Paraná, Brazil). Neotrop. Ichthyol. 4: 197-202.

Avise JC (1996). Introduction: The Scope of Conservation Genetics. In: Conservation Genetics: Case Histories from Nature. 1st edn. (Avise JC and Hamrick JL, eds.). Chapman and Hall, London, 1-9.

Benine RC, Castro RMC and Santos ACA (2007). A new Moenkhausia Eigenmann, 1903 (Ostariophysi: Characidae) from Chapada Diamantina, Rio Paraguaçu basin, Bahia, northeastern Brazil. Neotrop. Ichthyol. 5: 262.

Benine RC, Mariguela TC and Oliveira C (2009). New species of Moenkhausia Eigenmann, 1903 (Characiformes: Characidae) with comments on the Moenkhausia oligolepis species complex. Neotrop. Ichthyol. 7: 161-168.

Bertaco VA and Lucena CAS (2006). Two new species of Astyanax (Ostariophysi: Characiformes: Characidae) from eastern Brazil, with a synopsis of the Astyanax scabripinnis species complex. Neotrop. Ichthyol. 4: 53-60.

Bertollo LAC, Born GG, Dergam JA, Fenocchio AS, et al. (2000). A biodiversity approach in the Neotropical Erythrinidae fish Hoplias malabaricus. Karyotypic survey, geographic distribution of cytotypes and cytotaxonomic considerations. Chromosome Res. 8: 603-613.

Carvalho GR (1993). Evolutionary aspects of fish distribution: genetic variability and adaptation. J. Fish Biol. 43: 53-73.

Carvalho GR and Hauser L (1998). Advances in the molecular analysis of fish population structure. Ital. J. Zool. 65: 21-33.

Çiftci Y and Okumus I (2002). Fish population genetics and applications of molecular markers to fisheries and aquaculture: I- Basic principles of fish population genetics. Turkish J. Fish. Aquat. Sci. 2: 145-155.

Coyle T (1997). Stock Identification and Fisheries Management: the Importance of Using Several Methods in a Stock Identification Study. In: Taking Stock: Defining and Managing Shared Resources (Hancock DA, ed.). Australian Society for Fishery Biology, Sidney, 173-182.

de Brito Portela-Castro AL, Ferreira Júlio Júnior H and Belini NP (2000). New occurrence of microchromosomes B in Moenkhausia sanctaefilomenae (Pisces, Characidae) from the Parana River of Brazil: analysis of the synaptonemal complex. Genetica 110: 277-283.

Eigenmann CH (1903). New genera of South America fresh-water fishes, and new names for some old genera. Smithson. Collect. 45: 144-148.

Fernandes-Matioli FMC, Matioli SR and Almeida-Toledo LF (2000). Species diversity and geographic distribution of Gymnotus (Pisces: Gymnotiformes) by nuclear (GGAC)n microsatellite analysis. Genet. Mol. Biol. 23: 803-807.

Foresti F, Almeida-Toledo LF and Toledo-Filho SA (1989). Supernumerary chromosome system, C-banding pattern characterization and multiple nucleolus organizer regions in Moenkhausia sanctaefilomenae (Pisces, Characidae). Genetica 79: 107-114.

Froese R and Pauly D (2013). Fish Base. World Wide Web Electronic Publication. Available at [http://www.fishbase.org]. Accessed March 20, 2013.

Javonillo R, Malabarba LR, Weitzman SH and Burns JR (2010). Relationships among major lineages of characid fishes (Teleostei: Ostariophysi: Characiformes), based on molecular sequence data. Mol. Phylogenet. Evol. 54: 498-511.

Khattree R and Naik DN (2000). Multivariate Data Reduction and Discrimination with SAS Software. SAS Institute Inc., Cary.

Klug W and Cummings MR (1997). Concepts of Genetics. 5th edn. Prentice Hall, Miami.

Kumar S, Tamura K and Nei M (2004). MEGA3: Integrated software for Molecular Evolutionary Genetics Analysis and sequence alignment. Brief. Bioinform. 5: 150-163.

Lacy RC and Lindenmayer DB (1995). A simulation study of the impacts of population subdivision on the mountain brushtail possum Trichosurus caninus Ogilby (Phalangeridae: Marsupialia), in south-eastern Australia. II. Loss of genetic variation within and between subpopulations. Biol. Conserv. 73: 131-142.

Lalhruaitluanga H and Prasad MNV (2009). Comparative results of RAPD and ISSR markers for genetic diversity assessment in Melocanna baccifera Roxb. growing in Mizoram state of India. Afr. J. Biotechnol. 8: 6053-6062.

Leuzzi MSP, de Almeida FS, Orsi ML and Sodre LMK (2004). Analysis by RAPD of the genetic structure of Astyanax altiparanae (Pisces, Characiformes) in reservoirs on the Paranapanema River, Brazil. Genet. Mol. Biol. 27: 355-362.

Liu YG, Chen SL, Li J and Li BF (2006). Genetic diversity in three Japanese flounder (Paralichthys olivaceus) populations revealed by ISSR markers. Aquaculture 255: 565-572.

Lucinda PHF, Malabarba LR and Benine RC (2007). On a new species of the genus Moenkhausia Eigenmann (Ostariophysi: Characidae). Zootaxa 1525: 61-68. 
Lynch M (1996). A Quantitative-Genetic Perspective on Conservation Issues. In: Conservation Genetics: Case Histories from Nature (Avise JC and Hamricks JL, eds.). Chapman and Hall, London, 471-501.

Maltagliati F, Lai T, Casu M, Valdesalici S, et al. (2006). Identification of endangered Mediterranean cyprinodontiform fish by means of DNA inter-simple sequence repeats (ISSRs). Biochem. Syst. Ecol. 34: 626-634.

Mills C (2004). The Theory of Evolution: What it is, Where it Came from and Why it Works. John Wiley and Sons, New Jersey.

Mirande JM (2010). Phylogeny of the family Characidae (Teleostei: Characiformes): from characters to taxonomy. Neotrop. Ichthyol. 8: 385-568.

Moreira-Filho O and Bertollo LAC (1991). Astyanax scabripinnis (Pisces, Characidae): A species complex. Braz. J. Genet. 14: 331-357.

Moritz C (1994). Defining ‘Evolutionarily Significant Units’ for conservation. Trends Ecol. Evol. 9: 373-375.

Moysés CB, Daniel-Silva MF, Lopes CE and de Almeida-Toledo LF (2010). Cytotype-specific ISSR profiles and karyotypes in the Neotropical genus Eigenmannia (Teleostei: Gymnotiformes). Genetica 138: 179-189.

Nicoara M (2004). Biodiversity Conservation. Analele Ştiinţifice ale Universităţii, Al.I.Cuza” Iaşi, s. Biologie animală, Tom L, 183-194.

Oliveira C, Avelino GS, Abe KT, Mariguela TC, et al. (2011). Phylogenetic relationships within the speciose family Characidae (Teleostei: Ostariophysi: Characiformes) based on multilocus analysis and extensive ingroup sampling. BMC. Evol. Biol. 11: 275.

Pavlicek A, Hrda S and Flegr J (1999). Free-Tree - freeware program for construction of phylogenetic trees on the basis of distance data and bootstrap/jackknife analysis of the tree robustness. Application in the RAPD analysis of genus Frenkelia. Folia Biol. 45: 97-99.

Pazza R, Kavalco KF, Prioli SMAP, Prioli AJ, et al. (2007). Chromosome polymorphism in Astyanax fasciatus (Teleostei, Characidae). 3: Analysis of the RAPD and ISSR molecular markers. Biochem. Syst. Ecol. 35: 843-851.

Prioli SMAP, Prioli AJ, Júlio-Junior HF, Pavanelli CS, et al. (2002). Identification of Astyanax altiparanae (Teleostei, Characidae) in the Iguaçu River, Brazil, based on mitochondrial DNA and RAPD markers. Genet. Mol. Biol. 25: 421-430.

Rakoczy-Trojanowska M and Bolibok H (2004). Characteristics and a comparison of three classes of microsatellite-based markers and their application in plants. Cell Mol. Biol. Lett. 9: 221-238.

Reddy MP, Sarla N and Siddiq EA (2002). Inter simple sequence repeat (ISSR) polymorphism and its application in plant breeding. Euphytica 128: 9-17.

Sambrook J, Fritsch EF and Maniatis T (1989). Molecular Cloning: A Laboratory Manual. Cold Springs Harbor Laboratory Press, Long Island.

Zietkiewicz E, Rafalski A and Labuda D (1994). Genome fingerprinting by simple sequence repeat (SSR)-anchored polymerase chain reaction amplification. Genomics 20: 176-183. 